\title{
Comparative Assessment and Optimisation of Different DNA Extraction Methods in Lesser Yam (Dioscorea esculenta)
}

\author{
Visalakshichandra $^{1 *}$, M. N. Sheela ${ }^{1}$, A. S. Swathy ${ }^{2}$, \\ B. S. Prakash Krishnan ${ }^{1}$ and Vivek Hegde ${ }^{1}$ \\ ${ }^{1}$ ICAR-Central Tuber Crops Research Institute (ICAR-CTCRI), Sreekaryam, \\ Thiruvanathapuram, Kerala, India \\ ${ }^{2}$ A.J. College of Science and Technology, Thonnakkal, Thiruvanathapuram, Kerala, India \\ *Corresponding author
}

\section{A B S T R A C T}

Keywords

DNA extraction method, Dioscorea esculenta, Quality of DNA, commercial kit, PCR

Article Info

Accepted:

28 May2018

Available Online:

10 July 2018
The effectiveness of genotyping for any genetic studies relies on the quantity and quality of DNA isolated. The DNA isolation procedures differs for different crop species depending upon the phytochemical composition of the tissue used for isolation of DNA. The polyphenol abundance in Lesser yam interferes in the isolation of high quality DNA. The quantitative and qualitative assessment of DNA isolated using different extraction methods therefore becomes a priority. The selection of accurate isolation method becomes absolutely essential to obtain PCR amplification. In this study, five DNA extraction methods were compared in terms of quantity, quality/purity, time consumed, integrity and functionality. Among the DNA extraction methods analysed in this study, the Asemota method was found to be the most efficient in isolating high DNA yield with better quality from Dioscorea esculenta. The DNA extracted using this protocol can be used for wholegenome sequencing, advanced sequencing technologies, and bioinformatic tools.

\section{Introduction}

Lesser Yam (Dioscorea esculenta) belongs to the Yams family characterised by relatively smaller corms than other species with a size equivalent of potato and sweet potato.

Lesser yam is one of the prominent member of the Dioscorea family grown widely in Sub Saharan Africa, Asia, Central and South America.It is also known by other names such as Asiatic yam, Potato yam, Lesser Asiatic yam, Kangar, Karen potato etc. The edible part of the yam is the tuberwhich has abundance of carbohydrate therefore serves as good source of energy (Coursey, 1969). However the fat and protein content is lesser than most yam species. The tubers contain pharmacologically active substances like dioscorine, saponin and sapogenin. Moreover the tubers also serve as a source of Industrial starch and the quality of starch is found to be comparable to Cereal starch (Osisiogu, 1973). Thus in a word, Lesser yam is a versatile crop playing an important role in the development of agriculture in the tropics. 
The growing importance of this crop would lead to extensive genetic and molecular studies in near future. Most of the basic and advanced molecular techniques are found to be sensitive to the DNA quality. The presence of high levels of proteins, polyphenols, polysaccharides, and lipids and many types of secondary metabolites affects the yield and quality of DNA (Romano and Brasileiro, 1999; Hoy, 2003; Demeke and Jenkins, 2010). Certain polysaccharides are known to inhibit PCR reactions (Pandey et al., 1996). Lesser yam leaves are found to be high in polyphenols especially anthocyanins and phenolic acids which interferes in the isolation of good quality DNA. For advanced genetic studies, however, DNA of high quality and quality is essential. Furthermore, studies involving screening of large numbers of samples, such as evolutionary or breeding studies, require faster methods that reliably yield high-quality DNA.

Therefore selection of an efficient DNA extraction method is highly essential. Hence the current study was planned to conduct a comparative analysis of the different DNA isolation methods including manual and kit methods based on quantity, quality/purity, Integrity, time and functionality to determine the most efficient protocol for DNA extraction from the species in study.

\section{Materials and Methods}

\section{Plant material}

100 milligrams of young leaf tissues of lesser yam variety SreeLatha was collected during early hours of the day from ICAR-Central Tuber Crops Research Institute (ICARCTCRI), Thiruvananthapuram, India. The collected leaf samples were cleaned, wrapped in moist tissue papers and kept away from sunlight. The leaf samples were temporarily stored at $-80^{\circ} \mathrm{C}$ before taking out for isolation.

\section{Testing DNA extraction protocols}

The details of four DNA extraction protocols tried in the present study are given below:

CTAB method of DNA extraction by Doyle and Doyle (1987) with slight modifications

SDS method of DNA extraction by Dellaporta et al., (1983) with slight modifications

DNA extraction by Raj et al., (2013)

DNA extraction by Asemota (1990) with slight modifications

DNA extraction using commercial kit (Qiagen)

The reagents used in different methods are as follows:

\section{Method 1}

The first method was described by Doyle and Doyle (2009).

The Reagents used in this protocol: $1 \mathrm{ml}$ of extraction buffer (100 mMTris, pH8.0, 20mM ethylenediaminetetra acetic acid (EDTA), pH8.0, $1 \mathrm{M} \mathrm{NaCl}, 0.2 \% \beta$ mercaptoethanol), $70 \%$ ethanol, liquid nitrogen, Chloroform: Isoamyl alcohol (24:1), Ammonium acetate, TE buffer, Absolute ethanol).

\section{Method 2}

The second method was described by Dellaporta et al., (1983).

The reagents used in this protocol are: $1 \mathrm{ml}$ of extraction buffer (1 M Tris, $\mathrm{pH} 8.0,0.5 \mathrm{M}$

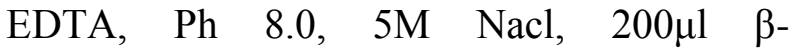
mercaptoethanol, 1\%PVP), 20\%SDS, 3M sodium acetate, Isopropanol, Liquid nitrogen, $5 \mathrm{M}$ potassium acetate. 


\section{Method 3}

The third method was explained by Raj et al., (2013). The reagents included in this protocol are: $1 \mathrm{ml}$ of extraction buffer $(100 \mathrm{Mm}$ Tris-cl, $\mathrm{pH} \quad 8.0,25 \mathrm{Mm}$ EDTA, $1.5 \mathrm{M}$ Nacl, $2.5 \% \mathrm{CTAB}, 0.2 \% \beta$-mercaptoethanol), $15 \mathrm{Mm}$ Ammonium acetate, TE buffer, Chloroform : Isoamyl (24:1), Wash solution.

\section{Method 4}

The fourth method was described by Asemota et al., (1990). The reagents in this protocol are: $1 \mathrm{ml}$ of isolation buffer $(100 \mathrm{Mm}$ Tris, $\mathrm{pH}$ 7.5, 50Mm EDTA, $\mathrm{pH}$ 8.0, $1 \mathrm{M}$ Nacl), Dissolution buffer (10Mm Tris-Hcl, pH 8.0, $1 \mathrm{Mm}$ EDTA), TE-RNAase (10Mm EDTA

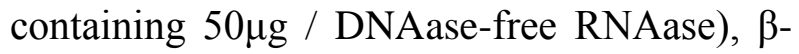
mercaptoethanol, Isopropanol, 70\%ethanol, $3 \mathrm{M}$ Sodium acetate $(\mathrm{pH} 5.2), 5 \mathrm{M}$ Pottasium acetate, $10 \% \mathrm{w} / \mathrm{v}$ SDS.

\section{Method 5}

The last method was done by using Qiagen Commercial kit according to the manufacturer's protocol

The DNA isolation protocol of five different methods are as follows:

\section{CTAB method of DNA extraction by Doyle and Doyle (1987)}

$200 \mathrm{mg}$ of plant tissue was ground into fine paste using liquid nitrogen. $1 \mathrm{ml}$ of pre-warmed extraction buffer was added and stirred well. The plant extract mixture was incubated at $65^{\circ} \mathrm{C}$ for about one hour in a recirculating water bath. Shaken at every 10 minutes to prevent precipitation. The plant extract mixture was spined at $10,000 \mathrm{rpm}$ for 10 minutes to spin down debris. The supernatant was transferred to fresh vials. $500 \mathrm{ml}$ of chloroform: isoamyl alcohol (24:1) was added and mixed the solution by inversion. The mixture was slowly mixed for 15 minutes to completely dissolve. After mixing properly, the tubes were centrifuged at 10,000 rpm for 10 minutes. The upper aquous phase was transferred into clean micro centrifuge tube and double volume of chilled isopropanol was added and mixed properly. The tubes were slowly inverted to precipitate the DNA out of solution. The tubes were placed overnight at $20^{\circ} \mathrm{C}$. Then the tubes were centrifuged at 10,000rpm for 15 minutes. The supernatant was discarded and $70 \%$ ethanol was added into it. Further centrifugation was carried out for 5 minutes at 5000rpm. The pellet was dried by inverting the tubes over tissue paper. The pellet was dissolved in 50 $\mu$ l TE buffer and stored at $-20^{\circ} \mathrm{C}$.

\section{SDS method of DNA extraction by Dellaporta et al., (1983)}

$1 \mathrm{~g}$ of young leaf tissue was weighed and ground to a fine powder using liquid nitrogen with mortar and pestle. Extraction buffer was added into the fine powder and it was transferred into oakridge tubes. Then it was kept at room temperature for 5 minutes. $1 \mathrm{ml}$ of $20 \%$ SDS was added to each tube and mixed well. The tubes were mixed thoroughly and incubated at $65^{\circ} \mathrm{C}$ in water bath for 10 minutes. Then $5 \mathrm{ml}$ of potassium acetate was added and mixed well. The solution was mixed thoroughly by vigorous shaking and incubated at $4^{\circ} \mathrm{C}$ for 30 minutes. The tubes were spined at 10,000rpm for 20 minutes. The upper layer of the solution was taken out and double volume of isopropanol was added and mixed well. The tubes were incubated at $4^{\circ} \mathrm{C}$ for overnight or for 5 -10 minutes in $-20^{\circ} \mathrm{C}$. Then centrifugation was carried out at $10,000 \mathrm{rpm}$, few minutes to remove other solution. The supernatent was discarded and resuspended the precipitated DNA in TE buffer or sterile water. Kept it in water bath at $65^{\circ} \mathrm{C}$ or dry bath for 10 minutes to dissolve the 
precipitated DNA. The DNA spool was taken out in $1.5 \mathrm{ml}$ eppendorf tubes and $5 \mu \mathrm{l}$ of RNAse was added and incubated at $37^{\circ} \mathrm{C}$ for one hour. Equal volume of chloroform: Isoamyl alcohol was added and mixed well and centrifuged at 10,000rpm for 20 minutes. The aqueous layer was taken out and $50 \mu \mathrm{l}$ of $3 \mathrm{M}$ sodium acetate and $500 \mu \mathrm{l}$ Pottasium acetate were added. Mixed well by inverting the tubes 20 times and centrifugation was carried out for 30swconds in a microfuge. Then the pelleted DNA was incubated at $20^{\circ} \mathrm{C}$ for 2 hours or $4^{\circ} \mathrm{C}$ for overnight. $500 \mu 1$ of $70 \%$ ethanol was added and centrifuged at 10,000rpm for 5 minutes. The DNA pellet was dried by inverting the tubes over tissue paper. Finally the DNA was resuspended in $500 \mu 1$ TE buffer or double distilled water.

\section{DNA Isolation method by Raj et al., (2013)}

$1 \mathrm{~g}$ of destarched leaf tissue was ground to a fine paste using liquid nitrogen. $1 \mathrm{ml}$ of prewarmed extraction buffer was added to the samples and ground once more. The samples were transferred to $2.0 \mathrm{ml}$ eppendorf tubes and $10 \mu 1$ proteinase $\mathrm{K}$ was added into it. The tubes were incubated on $37^{\circ} \mathrm{C}$ for 30 minutes. Kept it in water bath for 30 minutes with frequent swirling. Then the centrifugation was carried out at $12,000 \mathrm{rpm}$ for 15 minutes. Then the supernatant was transferred into fresh eppendorf tubes. The equal volume of Chloroform: Isoamyl was added into it and mixed by gentle inversion for 30-40 times. Samples were centrifuged at $12,000 \mathrm{rpm}, 10$ minutes. Then the supernatant was tranferred to a fresh tube. The above step was repeated again to remove any further proteins present. In the next step, $150 \mu \mathrm{l}$ of $2 \mathrm{M} \mathrm{Nacl}$ containing 4\% PEG was added. Then the centrifugation was carried out at 12,000 rpm for 10 minutes. The supernatant was transferred to a fresh tube and precipitated with $200 \mu \mathrm{l}$ of ethanol. The nucleic acid was precipitated and collected followed by centrifugation at $12,000 \mathrm{rpm}$ for
10 minutes. The nucleic acid pellet was washed twice with wash solution, air dried until the ethanol was removed and then it is dissolved in TE buffer. The nucleic acid dissolved in TE buffer were treated with ribonuclease. Then the incubation was carried out at $37^{\circ} \mathrm{C}$ and was stored ai $-20^{\circ} \mathrm{C}$ until use.

\section{DNA isolation method by Asemota et al., (1990)}

50-100 mg of fresh yam samples were weighed and ground with liquid nitrogen in $800 \mu \mathrm{l}$ of isolation buffer in a $1.5 \mathrm{ml}$ microcentrifuge tube with a suitably fixing glass rod. (For lyophilized samples, first grain the tissue to powder with sterile sand before addition of isolation buffer.14 $\mu \mathrm{l}$ of $\beta$ mercaptoethanol and $100 \mu 1$ of $10 \%$ SDS were added into it. The contents of the tubes were mixed vigorously and incubated at $65^{\circ} \mathrm{C}$ for 15 minutes. $350 \mu \mathrm{l}$ of $5 \mathrm{M}$ potassium acetate were added and shaken vigorously and cooled on ice for 5 minutes. The mixture was centrifuged at $12,000 \mathrm{rpm}$ for 5 minutes. The mixture was centrifuged at $12,000 \mathrm{rpm}$ for 15 minutes. The supernatant was transferred into microcentrifuge tube and $535 \mu 1$ of ice-cold $70 \%$ ethanol was added. The alcohol was drained off completely and DNA pellet was dried in air for 10 minutes. $120 \mu \mathrm{l}$ of dissolution buffer was added into the DNA pellet and the tubes were taped gently to dislodge pellet. Incubation was carried out at $55^{\circ} \mathrm{C}$ for 10 minutes. Mixing was done with the aid of cut micropipette tips. The DNA pellet was cooled on ice for 2 minutes. Then the supernatant was transferred to a new microcentrifuge tube and $120 \mu \mathrm{l}$ of $3 \mathrm{M}$, sodium acetate and $88 \mu \mathrm{l}$ of ice-cold isopropanol was added into it. Then incubation was carried out at $0^{\circ} \mathrm{C}$ for 5 minutes followed by centrifugation at 12,000 rpm for 5 minutes. The supernatant was drained off carefully and the DNA pellet was washed with 500ulof ice-cold ethanol. The 
ethanol was drained off and the DNA pellet was dried in air for 20 minutes. Finally the DNA pellet was re-dissolved in $60 \mu \mathrm{l}$ TERNAase.

\section{DNA isolation method by Qiagen Commercial kit}

$100-200 \mathrm{mg}$ of young leaves collected were weighed and ground in pestle and mortar using liquid nitrogen. 400 $\mu \mathrm{l}$ AP Buffer and $4 \mu 1$ RNase A were added into it. Vortexed and incubated for 10 minutes at $65^{\circ} \mathrm{C}$. The tubes were inverted 2-3 times during incubation. Mixed and incubated for 5 minutes on ice. The lysate was centrifuged for 5 minutes at 20,000x gg (14000rpm). The lysate was pipette into QIA shredder spin coloumn placed in a $2 \mathrm{ml}$ collection tube. Centrifuged for 2 minutes at $20,000 \times \mathrm{g}$. transferred the flothroygh into a new tube without disturbing the pellet if present. 1.5 volume of Buffer $\mathrm{AW}_{2}$ were added and mixed by pipetting. $650 \mu 1$ of the mixture was transferred into a Qiagen mini spin coloumn placed in a $2 \mathrm{ml}$ collection tube. Centrifuged for $1 \mathrm{~min}$ at $\geq 6000 \mathrm{x} \mathrm{g}$ ( $\geq 8000 \mathrm{rpm}$ ). Discarded the flow- through. Repeated this step with the remaining sample. The spin-coloumn was placed into a new $2 \mathrm{ml}$ collection tube. 500 $\mu \mathrm{l}$ Buffer $\mathrm{AW}_{2}$ were added and centrifuged for $1 \mathrm{~min}$ at $\geq 6000 \mathrm{x} \mathrm{g}$. Then the flow-through was discarded. Another $500 \mu \mathrm{l}$ Buffer $\mathrm{AW}_{2}$ were added into it. Centrifuged for 2 minutes at $20,000 \mathrm{x} \mathrm{g}$. The spin coloumn was removed from the collection tube carefully so that the coloumn doesn't come contact with the flow through. The spin coloumn was transferred into a new $1.5 \mathrm{ml}$ or $2 \mathrm{ml}$ microcentrifuhe tube. $100 \mathrm{c}$ Buffer AE was added for elution. Incubated for $5 \mathrm{~min}$ at room temperature $\left(15-25^{\circ} \mathrm{C}\right)$. Centrifuged for $1 \mathrm{~min}$ at $\geq 6000 \mathrm{x}$ g. The last step was repeated and kept the sample in $20^{\circ} \mathrm{C}$ refrigerator. All the samples were checked for DNA in 1\% agarose gel and confirmed. Qiagen Commercial kit was comparatively less time consuming. At the end of each method, DNA was air dried for 30 min (except for commercial kit) and diluted in $100 \mu \mathrm{l}$ of TE buffer (10mM Tris-vl, $\mathrm{pH} 7.4,1$ $\mathrm{mM}$ EDTA, PH 8.0). Each method was replicated four times.

Quantitative and Qualitative assessment of DNA

The isolated DNA was analysed by standard Agarose gel electrophoresis. The DNA obtained from each of the protocol $(5 \mu \mathrm{l})$ was stained with $1 \mathrm{X}$ gel loading dye, and analyzed on $0.8 \%$ agarose gels at $80 \mathrm{~V}$ in $1 \mathrm{X}$ TBE running buffer ( $90 \mathrm{mMTris}$ base, $90 \mathrm{mM}$ boric acid, and $2 \mathrm{mM}$ EDTA, $\mathrm{pH}$ 8.0). DNA bands were observed on a UV-transluminator, and images were scanned with an image capture system (G: box, Syngene). Electrophoresis not only ascertained the quantity and quality of DNA, but also the presence or absence of degraded molecules. The amount of DNA in the samples was compared with the high molecular marker DNA Mass Ladder (Takara) following manufacturer's protocol. All DNA samples were stored at $-20^{\circ} \mathrm{C}$ for later use in $\mathrm{PCR}$ reactions.

\section{DNA quantification using Nanodrop spectrophotometer}

The isolated DNA was quantified using Nanodrop spectrophotometer (NANODROP® ND-1000). It helped to assess the yield and purity of isolated DNA.TE buffer was used to calibrate the machine. The advantage of Nanodrop is that it requires only $1.5 \mu 1$ sample to measure its quantity and purity unlike normal spectrophotometer.

The yield was determined by measuring absorbance at OD 260 and the purity was determined by calculating OD 260/OD 280 ratio. According to the better absorbance value/ OD value samples were selected. 


\section{Integrity of DNA}

The integrity, i.e. presence of high molecular weight DNA was determined by both electrophoresis on $1 \%$ agarose gel as described above and restriction digestion analysis using the enzymes EcoR ${ }_{1}$ and Hind III and monitoring the banding profile of the completely digested genomic DNA.

The restriction recognition site for these enzymes are:

Eco RI: G/AATTC ATTAA/C Hind III: A/AGCTT TTCGA/A

$1 \mu 1$ buffer and $0.5 \mu 1$ restriction of enzyme was added into a clean microcentrifuge tube. $6.5 \mu 1$ water was also added into it. To the mixture, $2 \mu 1$ of DNA was added making up to a total volume of $10 \mu 1$.

Then it was kept for overnight incubation at $37^{\circ} \mathrm{C}$ followed by $65^{\circ} \mathrm{C}$ for 15 minutes. Before loading, $2 \mu 1$ of dye was added into it.10 $\mu$ of the samples were loaded in $1 \%$ agarose gel and electrophoresed.

\section{Functionality of DNA}

\section{PCR Amplification}

PCRs were performed with $2 \mu \mathrm{L}$ each, of the DNA extracted by the five protocols from Sreelatha variety of lesser yam. IISR primers UBC 827, (GA) ${ }_{9} \mathrm{AC}, \mathrm{ACC}_{6} \mathrm{Y}$ and $\mathrm{UBC} 811$ were used for PCR amplification. The reaction contained $1 \mathrm{X}$ reaction buffer $(500 \mathrm{mMTris}-$ $\mathrm{HCl}, \mathrm{pH} 8.5,150 \mathrm{mM}$ ammonium sulfate, $\mathrm{pH}$ 9.3, $25 \mathrm{mM} \mathrm{MgCl} 2$, and $1 \%$ Tween 20), $0.2 \mu \mathrm{M}$ of each primer, $0.2 \mathrm{mM}$ of each dNTP and 1.0 $\mathrm{U}$ of Taq DNA polymerase in a final volume of $20 \mu \mathrm{L}$. The reaction conditions followed an initial denaturation cycle at $94^{\circ} \mathrm{C}$ for $5 \mathrm{~min}$, followed by 30 cycles of $94^{\circ} \mathrm{C}$ for 1 $\min , 56.3^{\circ} \mathrm{C}$ for $1 \mathrm{~min}, 72^{\circ} \mathrm{C}$ for $2 \mathrm{~min}$, with a final extension at $72^{\circ} \mathrm{C}$ for $2 \mathrm{~min}$, in a thermocycler (ProFlexPCR system, Applied Biosystems). The amplified products were stained with 6XLoading Dye and analyzed by electrophoresis on $1 \%$ agarose gels at $90 \mathrm{~V}$. The size of the amplified fragment was estimated by comparing with corresponding bands on a 100 bp ladder (Takara).

\section{Time estimation}

The minimum time required to finish one extraction from $100 \mathrm{mg}$ tissue using each method was estimated based on the procedures used in this study, including the time for incubation, centrifugation and 30 minute for DNA drying if necessary. The time spent in grounding samples using liquid nitrogen in all the methods was excluded.

\section{Analysis of results}

Protocols were compared in terms of the quantity and quality of extracted DNA, time taken, integrity and functionality. The DNA extraction data were statistically analysed by ttest at 5\% probability level, using SAS 9.3 software.

\section{Results and Discussion}

\section{Choice of material}

Proper choice of plant material is very important for DNA extraction. In this research, the young yam leaves were collected from the ICAR-CTCRI yam field during early hours for all the isolation methods under study. Fresh young leaf tissue were preferred for DNA extraction since it contains less polyphenolic and terpenoid compounds than older tissue. Generally mature plant tissues are not preferred for DNA extraction due mainly to the presence of high concentrations of polysaccharides, poly phenols, and other secondary metabolites. 


\section{DNA Quantity}

The DNA yield from all the five extraction methods is listed in Table 1.The extraction method had a significant effect $(\mathrm{F}=8.84, \mathrm{df}=4$, $\mathrm{P}<0.01$ ) on the DNA yield (Table 2). The DNA yield obtained by the CTAB method was significantly higher than those obtained by the SDS methods and plant DNA kit method (Table 1). But there was some distinct shearing of DNA observed on agarose gel (Fig. 1). Raj et al., method of DNA isolation gave good yield next to $\mathrm{CTAB}$ method with a concentration of $1082 \mathrm{ng} / \mu \mathrm{l}$. Polyvinyl Pyrrolidone (PVP) used in this method enhanced the yield significantly. DNA extracted with the SDS method described by Dellaportaet al., did not yield good quantity. This extraction method for Dioscorea esculenta did not show acceptable results because the SDS buffer used in the protocol attached to the secondary metabolite thereby prevented extraction of DNA with high quantity. Asemota et al., method gave appreciable amount of DNA (638.21 ng/ $\mu \mathrm{l})$ with no shearing of DNA on agarose gel. Commercial kit gave comparatively less quantity of DNA (97.76 $\mathrm{ng} / \mu \mathrm{l})$ but quality of DNA was good than any other methods studied.

In terms of DNA yield, CTAB method stands out but considering the importance of the quality of DNA on agarose gel, DNA isolated using Asemota et al., and commercial kit are found to be the best.

\section{DNA Purity}

The assessment of the purity of a nucleic acid sample is often performed by a procedure commonly referred to as the $\mathrm{OD}_{260 / 280}$ ratio. Although this procedure was first described as a means to measure protein purity in the presence of nucleic acid contamination, it is most commonly used today to assess purity of nucleic acid samples. A pure sample of DNA has the ratio at 1.8. The mean OD 260/280 ratios for the five methods were higher than 1.8. The commercial kit method had ratio closer to 2 . The reason for such higher values was that no RNA disposal was attempted except Raj et al., method. Proteins from the cell soup are generally removed during extraction by denaturation and precipitation using chloroform and or phenol. But in Raj et al., proteinase $\mathrm{K}$ was used to purge the protein instead of chloroform isoamyl alcohol (24:1). In terms of purity of DNA, Commercial kit method gave best results than other methods.

\section{Integrity}

The integrity, i.e. presence of high molecular weight DNA was determined by restriction digestion analysis using the enzymes EcoR $_{1}$ and Hind II and monitoring the banding profile of the completely digested genomic DNA. Quality and integrity of the isolated nucleic acid will directly affect the results of all succeeding scientific research. The results showed that the isolated DNA was suitable for further downstream processing. Integrity can also be determined by electrophoresis on a $0.8 \%$ agarose gel. High molecular DNA bands with no smear were obtained from Dellaporta method, Asemota method and plant mini kit method indicating that DNA were pure and intact. While the DNA obtained from the method described by Raj et al., and CTAB method showed high molecular DNA bands with smear at the bottom, demonstrating that the DNA were intact but there existed some RNA or protein residues. In Fig. 2, the DNA was completely digested with $\mathrm{EcoR}_{1}$ and Hind II restriction enzymes, as evidenced by the characteristic "smearing " and the absence of the high molecular weight bands seen in the adjacent lane of undigested DNA. This further confirmed the purity of the DNA, free of polysaccharide and polyphenol contaminations. 
Complete digestion with restriction endonuclease and successful amplification in PCR indicated that all the DNA extractions were of high quality and functionality. Among Five DNA isolation methods, the DNA extracted by Asemota method showed good results in EcoR1 and Hind III digestion. The results indicated that the DNA isolated is suitable for further downstream applications. This shows the effectiveness of this protocol to replace commercially available kits.

\section{Functionality}

The functionality of the DNA is the most important factor in determining whether an isolation method is valid or not. Without high quality DNA, the downstream molecular manipulations like RAPD and AFLP are not feasible. There are atleast three main contaminants associated with plant DNA: polyphenolic compounds, polysaccharides and RNA. Polysaccharides which are difficult to separate from DNA, interfere with several biological enzymes such as polymerases, ligases and restriction endonucleases.

Moreover when polysaccharides are not removed, the DNA will not amplified in PCR reaction. Polymerase chain reaction (PCR) using ISSR markers UBC 827, (GA) 9 AC, $\mathrm{ACC}_{6} \mathrm{Y}$ and UBC811 was carried out to compare the quality and functionality of extracted DNA. The results showed that the extracted DNA showed good amplification for all the methods studied (Fig.3)

Table.1 DNA yield, OD260/280 ratios, and estimated time used for one lesser yam isolation from $100 \mathrm{mg}$ leaf tissue by five extraction methods

\begin{tabular}{|c|c|c|c|c|}
\hline \multirow[t]{2}{*}{ Method } & \multirow{2}{*}{$\begin{array}{l}\text { DNA } \quad \text { yield } \\
(\mathrm{ng} / \mu \mathrm{l})\end{array}$} & \multicolumn{2}{|c|}{$\mathrm{OD}_{260 / 280}$ Value } & \multirow[t]{2}{*}{ Time (hr) } \\
\hline & & Mean & Range & \\
\hline CTAB method & 2234.95 & 2.11 & 1.98-2.19 & 3.1 \\
\hline Dellaporta method & 225.05 & 2.22 & $2.20-2.23$ & 7.32 \\
\hline Raj method & 1082.08 & 2.19 & $2.17-2.23$ & 2.01 \\
\hline Asemota method & 638.21 & 2.24 & $2.21-2.33$ & 1.08 \\
\hline Commercial kit & 97.76 & 2.03 & $1.96-2.16$ & 0.7 \\
\hline
\end{tabular}

Table.2 Variance analysis of DNA yield in five extraction methods

\begin{tabular}{|l|l|l|l|l|l|} 
Significance & Pr>F & F & Mean of Squares & df & Source \\
\hline NS & 0.4869 & 0.8627 & 288059.6175 & 3 & Replication \\
\hline Significant at 1\% & $0.0014^{* *}$ & 8.8480 & 2954304.2931 & 4 & Treatment \\
\hline & & & 333896.5854 & 12 & Error \\
\hline & & & & 19 & Total \\
\hline
\end{tabular}

** - Significant at 1\%, * - Significant at 5\%, NS - Non Significant 
Fig.1 Agarose gel of DNA isolated using different methods. Lanes 1-4 are the DNA isolated by

Doyle et al., lanes 5-8 are the DNA isolated by Dellaporta et al., lanes $9-12$ are the DNA isolated by Raj et a.l, lanes 13 -16 are DNA isolated by Asemota et al., lanes 17 -20 are the DNA isolated using Qiagen commercial kit

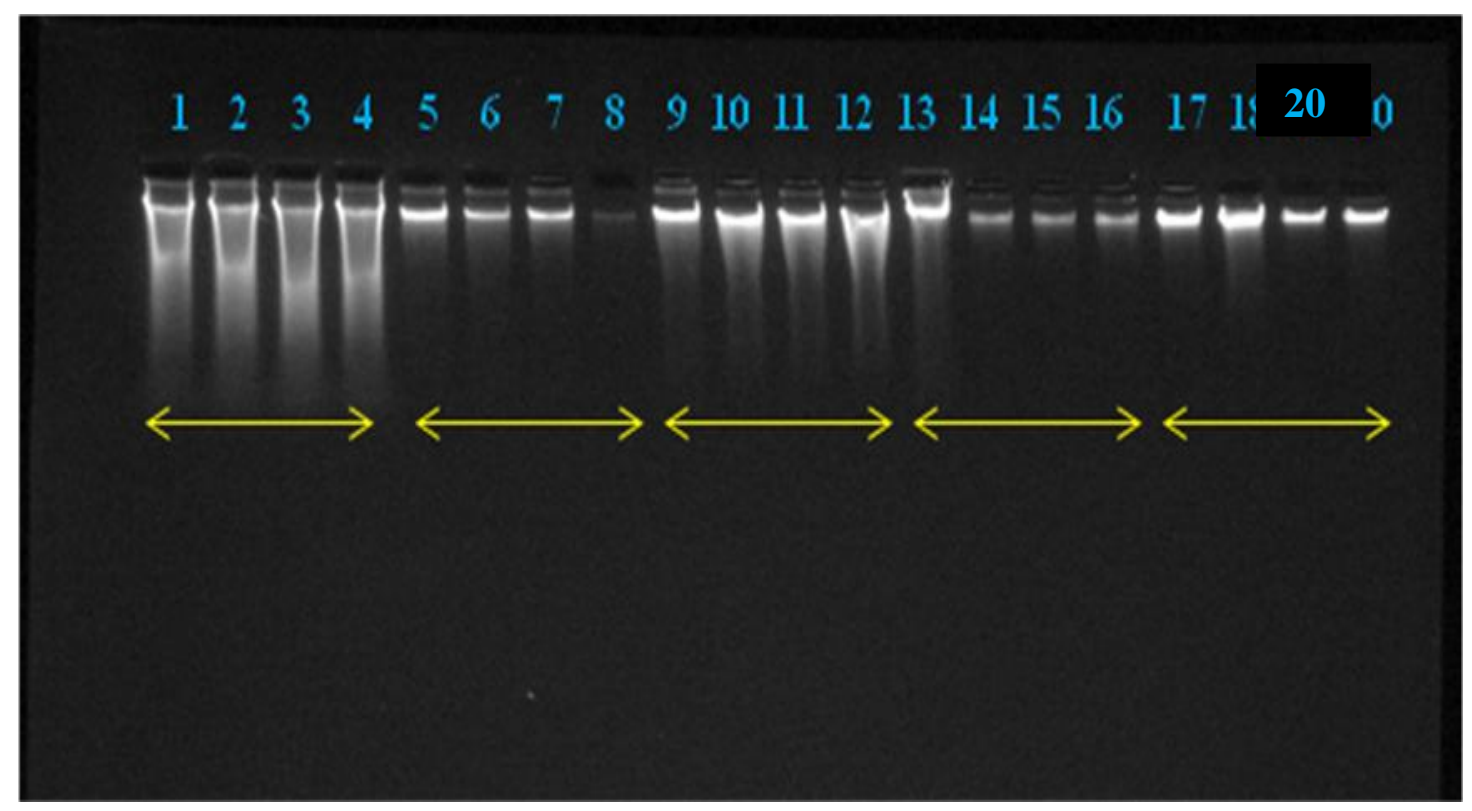

Fig.2 Agarose gel of undigested and digested DNA extracted from lesser yam young leaves. The isolated dna was digested by the restriction enzyme EcoR1. Lanes 1 and 2 are the DNA isolated by Doyle et al., lanes 3 and 4 are the DNA isolated by Dellaporta et al., lanes 5 and 6 are the DNA isolated by Raj et al., method, lanes 7 and 8 are DNA isolated by Asemota et al., and lanes 9 and 10 are the DNA isolated using Qiagen commercial kit alternating undigested and digested DNA

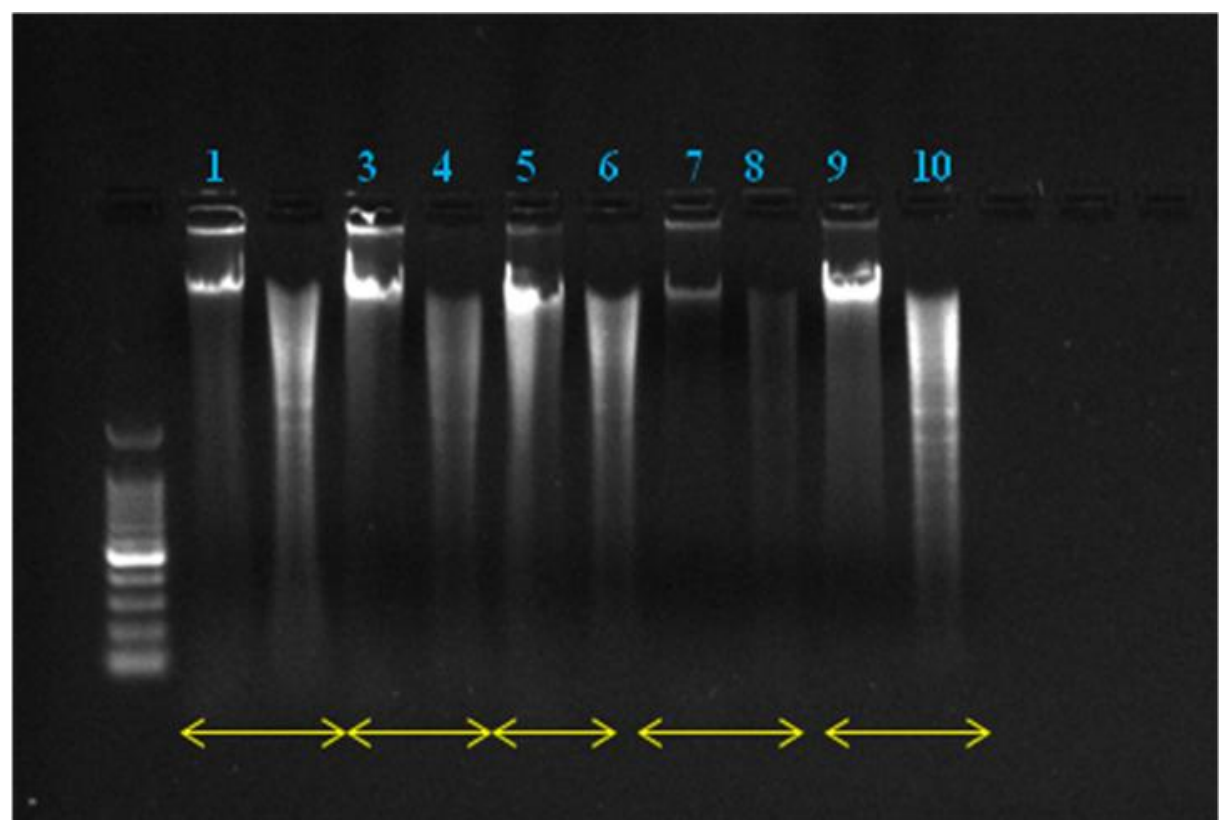


Fig.3 PCR amplification of DNA isolated using different methods.

Lanes 1-2 are the DNA isolated by Doyle et al., lanes 3\&4 are the DNA isolated by Dellaporta et al., lanes $5 \& 6$ are the DNA isolated by Raj et al., lanes $7 \& 8$ are DNA isolated by Asemota et al., lanes $9 \& 10$ are the DNA isolated using Qiagen commercial kit
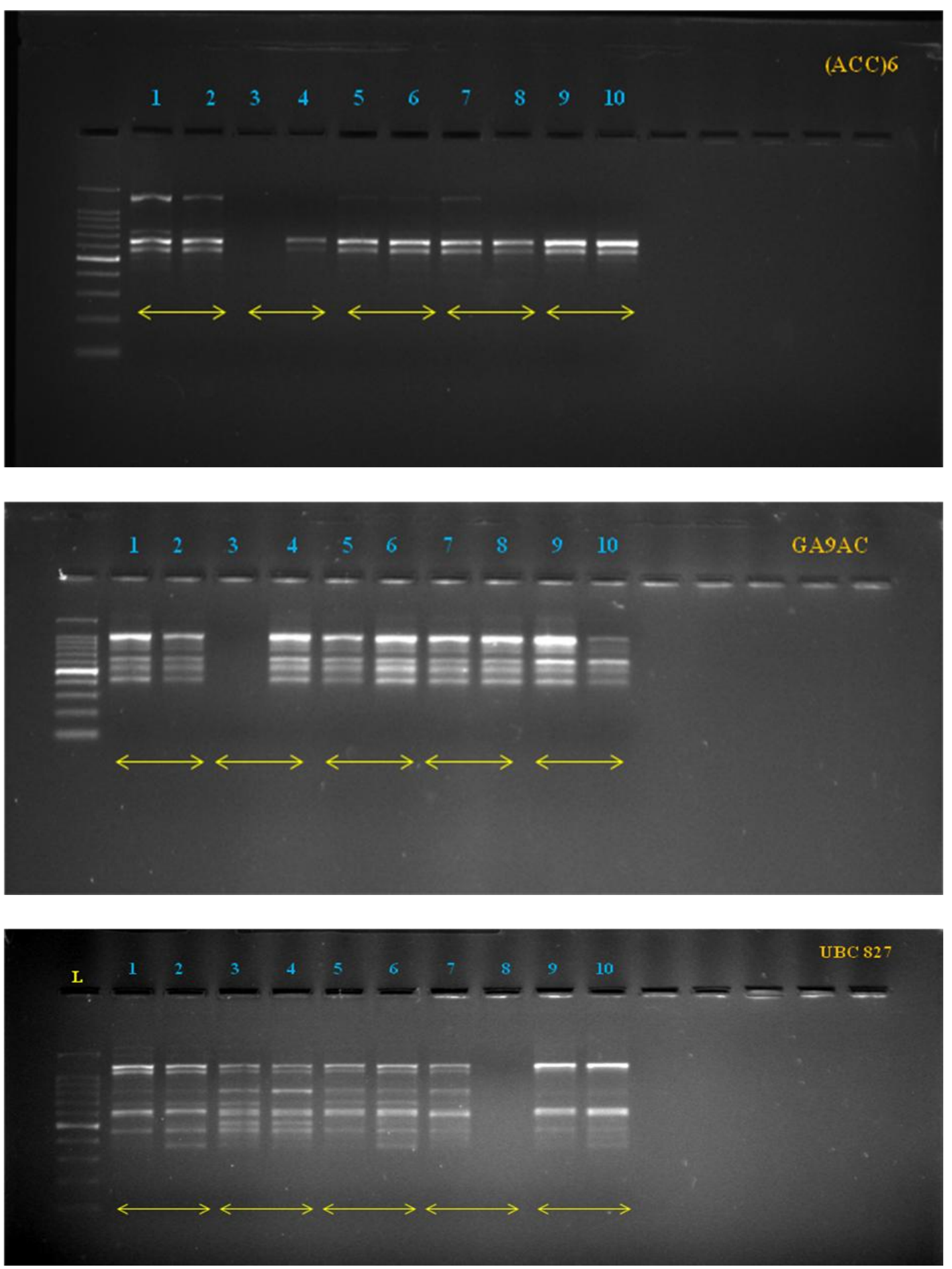


\section{Time consumed}

The time estimation is very essential to find an ideal method of DNA isolation. In order to perform PCR technique routinely, lesser time per assay is very important. The preparation time for each method showed no statistical difference, considering that Dellaporta method was the slowest, taking 7.32 hours to complete the DNA extraction (Table 1). The commercial kit took lesser time (0.7 hours) for isolation of DNA.

Therefore it can be concluded that in terms of time, Commercial kit method stands first followed by Asemota method, Raj et al., method, CTAB method and Dellaporta method.

In this study four manual methods and a commercial kit for isolating DNA from lesser yam were compared and analysed in terms of their time demands, yield of DNA, the purity of DNA, intergrity and functionality. After evaluating yield, purity, integrity and functionality among five methods, the commercial kit method and Asemota method described by Helen. N. Asemota were found to be ideal protocols to isolate DNA from Dioscorea esculenta.

However considering the cost effectiveness, Asemota method would be more suitable than the kit method. Besides, the quantity and the quality of the DNA extracted by this method were high enough to perform hundreds of PCR-based reactions and also to be used in other DNA manipulation techniques such as restriction digestion, southern blot and cloning.

\section{Acknowledgments}

The authors acknowledge the infrastructural and financial support from Division of Crop Improvement, ICAR-CTCRI.

\section{References}

Coursey, D.G. 1967. Yams. An account of the nature, origins, cultivation, and utilisation of the useful members of the Dioscoreaceae. Longmans, Green and Co, London.

Dellaporta, S. L., Wood, J., and Ticks, J. B. 1983. Aplant molecular DNA mini preperation 2. Plant Molecular Biology Reporter, (1): 1921.

Demeke, T and Jenkins, G.R. 2010. Influence of DNA extraction methods, PCR inhibitors and quantification methods on realtime PCR assay of biotechnology-derived traits. Anal. Bioanal. Chem. 396: 1977-1990

Doyle, J.J., and Doyle, J.L. 1987. A rapid DNA isolation procedure for small quantities of fresh leaf tissue. Phytochemical Bulletin, $19,11-15$.

Hoy, M.A. 2003. Insect molecular genetics. An introduction to principles and applications. Academic Press/Elsevier, San Diego, CA.

Mithun, Raj, Vishnu S. Nath., Senthil@Sankar, M., Pravi, V., Archana, P. V., Jeeva, M.L and Vinayaka Hedge 2013. Rapid isolation of DNA from Dioscorea species suitable for PCR, Restriction digestion and pathogen screening. Journal of Root Crops, Vol. 39 No. 2, pp. 163-167.

Osisiogu, I.U.W. 1973. Industrial potentials of some yam and cocoyam starches. Tropical Science, 15 (1973), pp. 353-359

Pandey, R.N., Adams, R.P and Flournoy, L.E. 1996. Inhibition of Random Amplified Polymorphic DNAs (RAPDs) by plant polysaccharides. Plant Mol. Biol. Rep. 14: 17-22.

Romano, E and Brasileiro, A.C.M. 1999. Extração de DNA de plantas. Biotecnolog. Cienc. Desenvolv. 9: 40-43.

\section{How to cite this article:}

Visalakshichandra, M. N. Sheela, A. S. Swathy, B. S. Prakash Krishnan and Vivek Hegde. 2018. Comparative Assessment and Optimisation of Different DNA Extraction Methods in Lesser Yam (Dioscorea esculenta). Int.J.Curr.Microbiol.App.Sci. 7(02): 4308-4318. doi: https://doi.org/10.20546/ijcmas.2018.707.502 